\title{
Cystitis treatment with phytotherapy within the Rif, Northern Morocco
}

\author{
Noureddine Chaachouay $^{1 *}$ D, Hicham Orch $^{2}$ and Lahcen Zidane ${ }^{2}$
}

\begin{abstract}
Background: Cystitis is often caused by a bacterial infection, which is the most widespread type among other urinary infections. This investigation was aimed to document detailed ethnobotanical information of medicinal plants used to heal cystitis problems because of their effective therapeutic properties. The study was carried in the Rif, from March 1 , 2015, to April 15, 2017. Semi-structured direct interviews were carried with 657 interviewees to collect the indigenous therapeutic knowledge. Surveys included interviewed demographic profile and ethnomedicinal information. UR and MUV were applied in data analysis.

Results: A total of 60 plant species distributed in 51 genera and 31 families were commonly used by our interviewees in the therapy of cystitis. Apiaceae was designed by the highest number of species (7 species); Capparis spinosa L. was the medicinal plant most frequently prescribed by regional people. Leaves were the most commonly used plant part (41.5\%), and the majority of herbal remedies were prepared from decoction (55\%).

Conclusions: This research is the first contribution to the ethnobotanical study of this region. It is suggested that the ingredients of natural plant species documented are being investigated to discover the therapeutic effects and mechanisms of action. Primary consideration must be paid to the preservation of medicinal species, comprehensive documentation of popular medicinal data, and biological validation of listed species.
\end{abstract}

Keywords: Rif, Morocco, Phytotherapy, Cystitis, Ethnomedicinal, Knowledge

\section{Background}

Urinary infections are a real public health problem around the world. Infections are classified as urethritis, simple acute cystitis, recurrent acute cystitis, simple acute pyelonephritis, and urinary infection of pregnant and postmenopausal women [1].

Cystitis (Nboula in the Moroccan dialect) is a medical term that describes inflammation of the bladder. Inflammation is most usually produced by a bacterial infection (Escherichia coli, Proteus, and Enterobacter), called a urinary tract infection. A bladder infection can be painful and irritating and can display a dangerous health difficulty if the infection reaches the kidneys.

\footnotetext{
* Correspondence: nour.chay@gmail.com

${ }^{1}$ Higher School of Education and Training, Berrechid, University Hassan, 1st, 50 Rue Ibnou Lhaytham B.P. 577, 26002 Settat, Morocco

Full list of author information is available at the end of the article
}

The specificity of the management of urinary infections in Morocco lies in the difficulties of accessing care, whether in private or public health facilities. Besides, the evaluation of the management and follow-up of the patient is unknown, as well as the evolution of resistance and the misuse of antibiotics.

Today, despite the development of chemical drugs to combat urinary tract diseases, there is often a return to plants as a source of active ingredients. Besides, an important part of the population, especially in rural areas, prefers medicinal plants, for economic reasons and sometimes because of difficulty in accessing medical care. It is also added that between 8 and 65\% of Escherichia coli associated with urinary infections are resistant to ciprofloxacin, an antibiotic commonly used against these infections [2].

This research aims to establish, from an ethnobotanical survey of local people, the list of plant drugs available in 
the Rif and that are used in the treatment of cystitis. We suggest, subsequently, a classification of these medicinal plant species reported, according to the use, and we present them in the form of a catalog.

\section{Methods}

\section{Study area}

The current study was conducted out in the Rif region. It extends between 34 and $36^{\circ}$ of latitude in the North and 4 to $6^{\circ}$ of longitude in the East. It is bounded in the North by the Strait of Gibraltar and the Mediterranean Sea, in the South by the RabatSale-Kenitra region and Fez-Meknes region, in the East by the Eastern Region, and in the West by the Atlantic Ocean (Fig. 1). The total geographical area of the Rif is $11,570 \mathrm{~km}^{2}$, and the population of the city is about 3,549,512 inhabitants with an average population density of $222.2 / \mathrm{km}^{2}$ [3]. The Rif is marked by Mediterranean weather with the highest temperature up to $45^{\circ} \mathrm{C}$ during summer (July-August) and below 0
${ }^{\circ} \mathrm{C}$ during winter (December-January), and the average annual rainfall ranges from 700 to $1300 \mathrm{~mm}$ which falls mainly between October and February [4]. The area is dominated by species such as Abies marocana Trab., Pinus halepensis Mill., Cannabis sativa L., and Cedrus atlantica (Endl.). The population is mixed between Arabic and Amazigh ethnicity. Principally, families of this region are very much dependent on subsistence farming, livestock, and, to a more secondary space, forest resources for their livelihood.

\section{Methodology}

\section{Ethnobotanical data collection}

To document an indigenous anticystitis plant ancestral knowledge and discover the level of utilization of traditional medicinal plants for prevention and therapy of cystitis by the local people (Fig. 2) (412 males and 245 females) from different rural and urban communes of the Rif region, namely, $S_{1}$ : Al Hoceim (30), $S_{2}$ : Ajdir (20), $S_{3}$ : Izefzafen (15), $S_{4}$ : Bni Hadifa (15), $S_{5}$ : Targuist

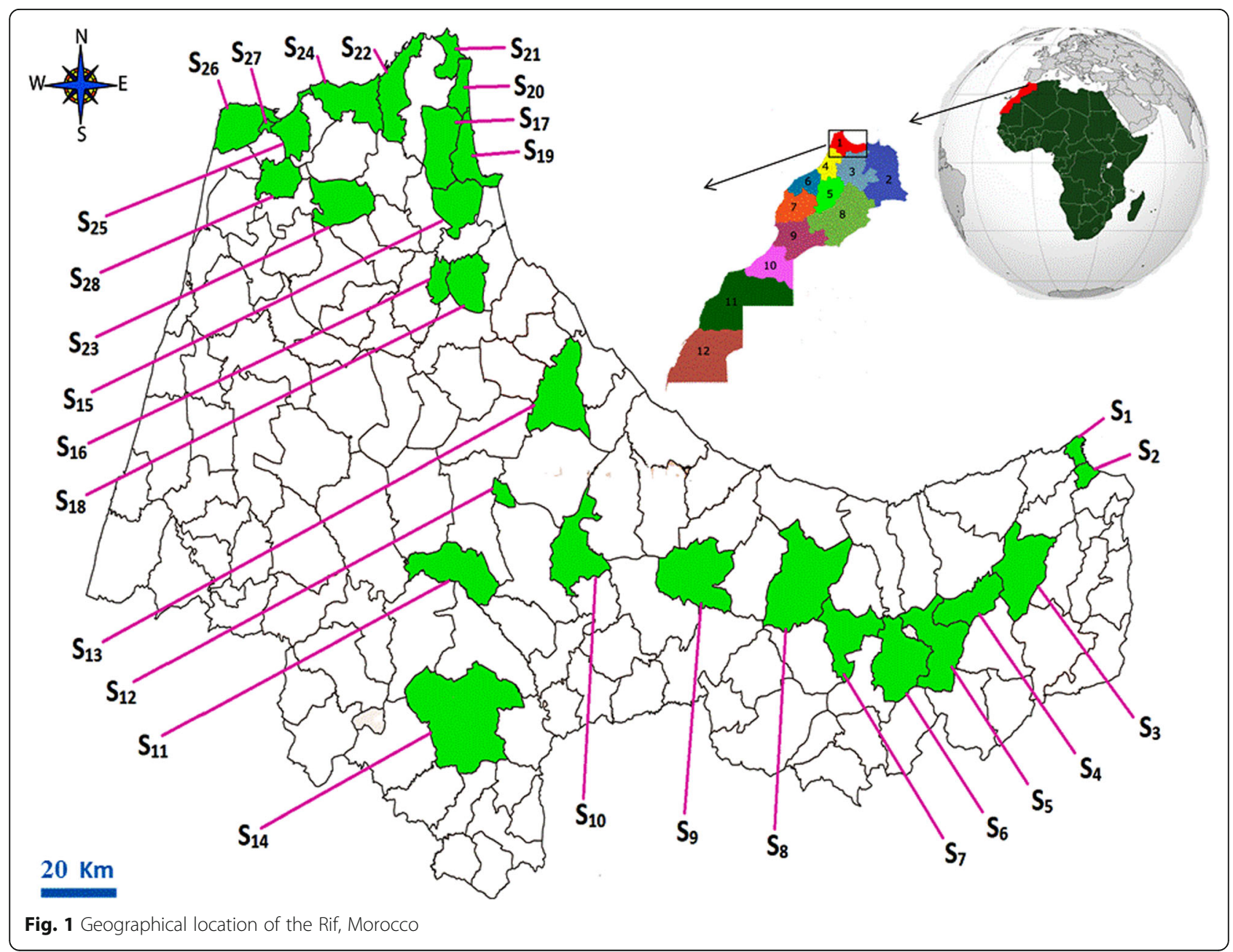




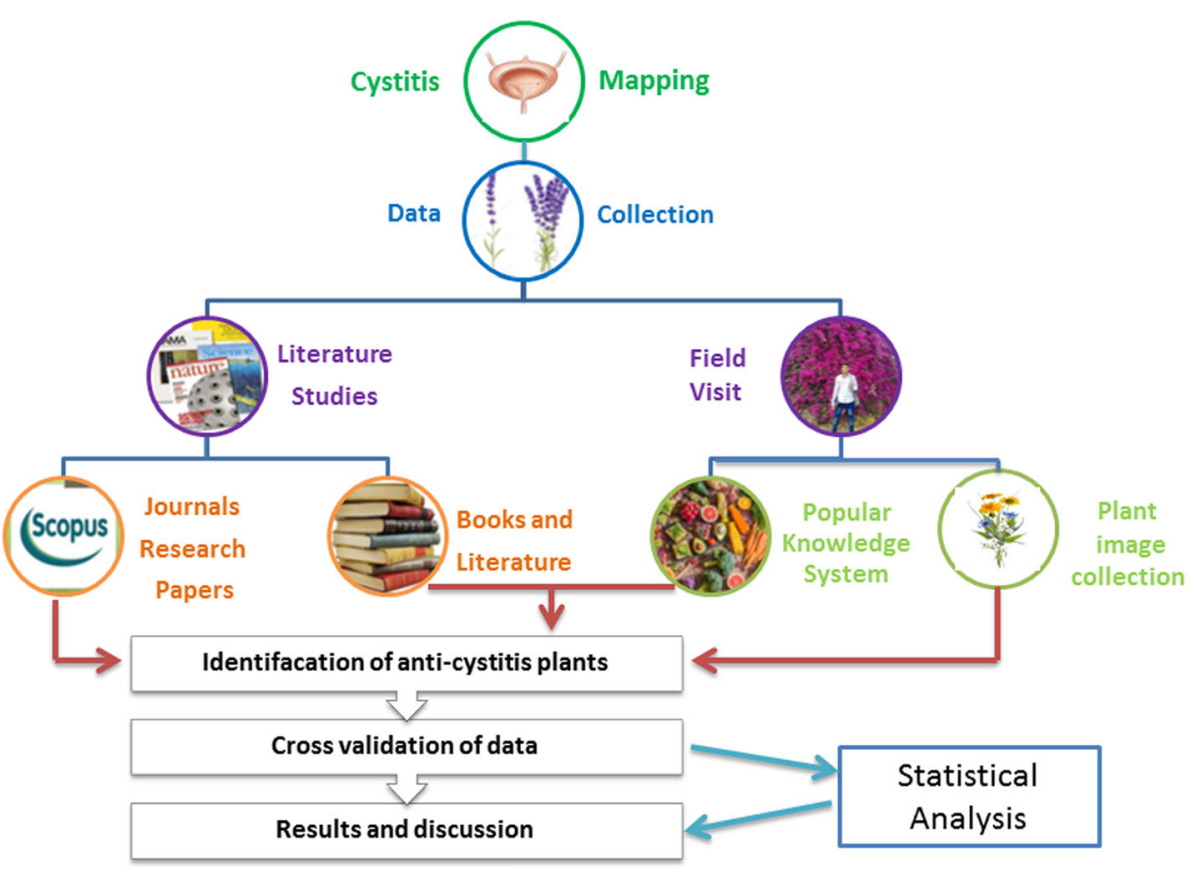

Fig. 2 Schematic flowchart for the identification of anticystitis plants

(25), $\mathrm{S}_{6}$ : Tizi n Tchin (22), $\mathrm{S}_{7}$ : Issaguen (30), $\mathrm{S}_{8}$ : Bab Berred (30), S : Cherrafate (30), $\mathrm{S}_{10}$ : Bab Taza (20), $S_{11}$ : Derdara (10), $S_{12}$ : Chefchaouen (30), $S_{13}$ : Akchour (30), $S_{14}$ : Fifi (30), $S_{15}$ : Tétouan (30), $S_{16}$ : Bni Karrich (30), $S_{17}$ : Mallalyène (15), $S_{18}$ : Zinat (30), $S_{19}$ : Martil (20), $\mathrm{S}_{20}$ : Md'q (20), $\mathrm{S}_{21}$ : Fnideq (20), $\mathrm{S}_{22}$ : Belyounich (30), $S_{23}$ : Melloussa (30), $S_{24}$ : Ksar Esghir (25), $S_{25}$ : Bni Ouassin (15), $S_{26}$ : Tanger (30), $S_{27}$ : Al Bahraouiyne (15), and $S_{28}$ : Jouamaa (10), a semi-structured questionnaire was prepared, and data were collected through face-to-face interviews over a period between March 1, 2015, and April 15, 2017.

The information collected during this study includes the sociodemographic characteristics of the surveyed (age, gender, level academic) and ethnobotanical data, including the local and scientific name of the species, local names, plant parts used, methods of use, preservation technique, administration mode, and toxicity (Appendix). Interviews were generally carried in the local language (Arab dialect and Tamazight); all documented data were then translated to English.

\section{Taxonomic nomenclature of the plant species}

Medicinal species being mentioned by the informants were registered with local names and photographed. For each reported plant species, the plant species were accumulated and classified, and voucher specimens were archived. The identification and nomenclature of the collected vegetal material were done first in the field and completed at the Plant, Animal Productions and Agroindustry Laboratory by one of the authors using some floristic literatures as well as The medicinal plants of Morocco [5]; Practical Flora of Morocco; tomes I, II, and III [6-8]; and Catalogs of vascular plants of northern Morocco, including identification keys and tomes I and II [9]. Taxonomy and denominations of species were validated using "The Plant List 2020" database (http:// www.theplantlist.org). Voucher specimens have been kept at our university, for future reference.

\section{Statistical analysis}

The data collected from the field and obtained from the local people were organized and studied with the statistical program IBM SPSS Statistics 21 Premium (SPSS 2019), to determine the proportions of various variable sociodemographics of the interviewees and ethnobotanical data. Quantitative value records were also determined for the general practices of these medicinal plants using the use reports (UR) and medicinal use value (MUV).

\section{Use reports (UR)}

The use reports (UR) of a plant or its significance in the practice of a community is recognized by its mentioning degree or its mention frequency by informants. It was determined by the formula [10]: UR $=\frac{N_{i}}{n}$ where $N_{i}$ is the 
sum of the informant who cited the species and $n$ is the entire of respondents interviewed.

\section{Medicinal use value (MUV)}

The MUV of documented therapeutic plants was defined by using this formula [11]: $\mathrm{MUV}=\frac{\sum U R_{i}}{N}$ where $\Sigma U R_{i}$ is the total sum of use reports per plants and $N$ is the total of interviewees interrogated for given medicinal species. The MUV rate will be more significant if there are several useful reports for a species, indicating that the plant is significant, whereas they will be near 0 if there are few reports compared to its use [12].

\section{Results}

Demographic information of informants

A total of 657 study informants, including 213 herbalists, 178 herbal sellers, 46 pharmacists, 40 midwives, and 180 other healers (bonesetters, Fouqha, cautery installer, farmers, elder people, and nobles), were interrogated using semistructured surveys and group interviews. In the study area, both sexes are interested in phytotherapy. However, the numbers of male participants were more important (412 informants) than those of females (245 informants). In this study, results showed that the utilization of medicinal species is widespread in all age groups with different percentages. The bulk of informants surveyed were over 50 years old (350), and between 30 and 50 years old (304), while 3 of the informants were aged less than 30 years old. Concerning the educational level, our results revealed that the majority of the informants (43\%) were uneducated, $29.4 \%$ have secondary education, $26.8 \%$ have primary education, and only $0.8 \%$ of the informants had high education (Table 1).

\section{Botanical families of plants used}

This investigation revealed that a total of 60 plant species belonging to 51 genera and 31 families were commonly used by local people from the Rif region in the treatment of cystitis. The family Apiaceae was designed by the largest number of plant species (7 species), followed by Ericaceae with 6 species; Lamiaceae, Poaceae, and Rutaceae (4 species each); and Asteraceae and Caryophyllaceae (3 species each), whereas the rest of botanical families were represented by one or two species in each. The vernacular names, scientific names of documented species, their families, mode of preparations, used parts, MUV, and UR are illustrated in Table 2.

\section{Medicinal use plants (MUV)}

MUV is used to find the most frequently used plant species in the study area. Its value ranged from 0.200 to 0.277 (Table 2). The calculated results of MUV showed
Table 1 Demographic profile of the informants $(n=657)$

\begin{tabular}{llll}
\hline Variables & Categories & Number of informants & $\%$ \\
\hline Sex & Male & 412 & 62.7 \\
Age groups & Female & 245 & 37.3 \\
& Less 30 years & 3 & 0.5 \\
& Between 30 and 50 & 304 & 46.3 \\
& Above 50 years & 350 & 53.2 \\
Educational level & Illiterate & 283 & 43 \\
& Primary & 176 & 26.8 \\
& Secondary & 193 & 29.4 \\
& University & 5 & 0.8 \\
Profession & Herbalist & 213 & 32.4 \\
& Herb seller & 178 & 27.1 \\
& Pharmacist & 46 & 7 \\
& Midwives & 40 & 6.1 \\
& Other healers & 180 & 27.4 \\
\hline
\end{tabular}

that Capparis spinosa L. was ranked first $(\mathrm{MUV}=0.277)$ followed by Apium graveolens L. (MUV=0.267), Zizyphus vulgaris Lam. (MUV=0.247), Herniaria glabra L. (MUV=0.233), Anethum graveolens L. (MUV=0.224), Spergularia rubra (L.) J.Presl \& C.Presl (MUV=0.216), and Nigella sativa L. (MUV=0.210), while the lowest value was found for Citrus reticulata Blanco., Convolvulus althaeoides L., and Eleusine indica (L.) Gaertn. (MUV=0.200 each).

\section{Parts of the plant used}

In the Rif region, indigenous people collect diverse plant parts for the preparation of phytotherapy (e.g., seed, root, flower, and leaf). The discussion result revealed that leaves are the most frequently used part of the medicinal plants $41.5 \%$ of the sum, followed by the whole plant $(26.5 \%)$, fruit $(10 \%)$, seed $(9 \%)$, flower $(7 \%)$, and rhizome (6\%).

\section{Modes and routes of medicine preparation}

The preparation of herbal remedies needs liquids. The main solution was water, but milk, butter, tea, and honey are also used by the Rif's population. The principal method of traditional medicine preparation reported was decoction (55\%), followed by infusion (33.1\%), cataplasm $(1.4 \%)$, and cooking (1.1\%). The percentage of the other modes of preparation grouped (fumigation, bath, maceration, powder, and plaster) does not exceed 9.4\%. Concerning the route of administration, the majority of informants' prepared remedies were applied mostly by oral $(73.2 \%)$ followed by topical $(18.7 \%)$ and dermal $(8.1 \%)$. 
Table 2 Catalog of medicinal plants used to treat cystitis problems in the Rif, Morocco

\begin{tabular}{llll}
\hline Family and scientific name & Vernacular name & Used parts & Preparation mode \\
\hline Amaranthaceae &
\end{tabular}

Route of administration

UR

MUV

Atriplex halimus L.

Legtef

Leaf

Infusion

Oral

03

0.005

Anacardiaceae

Pistacia lentiscus L.

Drou

Leaf

Infusion

Topical

97

0.145

\section{Apiaceae}

Ammi visnaga (L.) Lam.

Anethum graveolens $\mathrm{L}$.

Apium graveolens $\mathrm{L}$.

Conium maculatum L.

Ferula communis $\mathrm{L}$.

Petroselinum sativum Hoffm.

Pimpinella anisum $\mathrm{L}$.

\section{Apocynaceae}

Caralluma europaea (Guss.) N.E.Br.

Khella
Karwiya Amia
Lkrafes
Choukran
Lkalkha
Maâdnous
Habbat Hlawa

Asparagus officinalis $\mathrm{L}$.

Urginea maritima $\mathrm{L}$.

\section{Asteraceae}

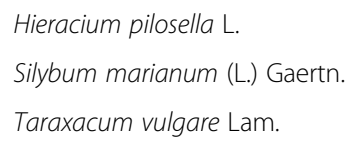

\section{Betulaceae}

Betula pendula Roth

\section{Boraginaceae}

Borago officinalis $\mathrm{L}$.

\section{Brassicaceae}

Nasturtium officinale R.Br.

\section{Cactaceae}

Opuntia vulgaris Mill.

\section{Capparaceae}

Capparis spinosa $\mathrm{L}$.

\section{Caryophyllaceae}

Corrigiola telephiifolia Pourr.
Herniaria glabra L.
Spergularia rubra (L.) J.Presl \& C.Presl

\section{Cucurbitaceae}

Cucurbita pepo L.

\section{Cupressaceae}

\footnotetext{
Juniperus communis L.

Tetraclinis articulata (Vahl) Mast.
}

Fruit

Infusion

Leaf

Cataplasm

Rhizome Decoction

Sekkoum

Nakhil Florida

Berztem

Bsel Edib, Ansel

Whole plant

Other

Wden Lfar

Tawra,

Lhindbae, Ûdjem

Whole plant

Decoction

Decoction

Decoction

Al Kodban

Whole plant

Infusion

Harricha, Lsan Tor

Flower

Infusion

Leaf

Decoction

Flower

Decoction

Leaf

Decoction

Whole plant

Decoction

Whole plant

Leaf

Decoction

Infusion

Seed

Decoction

Leaf

Leaf

Decoction

Decoction

Araar

Herras Lehjar

Lgraa Lhamra

.

Fruit

Decoction

Whole plant

Infusion

Whole plant

Infusion

Leaf

Cataplasm

Leaf

Leaf

seed

Decoction

Decoction

Other

Daghmous

Leaf

Infusion

Oral

Oral

Oral

Oral

Topical

Oral

Oral

Oral

Topical

Dermal

Topical

Dermal

Oral

Dermal

Oral

Oral

Oral

02

0.003

Oral

Oral

Oral

$142 \quad 0.216$

Dermal

25

0.038

Topical

45

0.068

Dermal

87

0.132

Decoction 
Table 2 Catalog of medicinal plants used to treat cystitis problems in the Rif, Morocco (Continued)

\begin{tabular}{|c|c|c|c|c|c|c|}
\hline Family and scientific name & Vernacular name & Used parts & Preparation mode & Route of administration & UR & MUV \\
\hline \multicolumn{7}{|l|}{ Ericaceae } \\
\hline Erica australis L. & Bouhadad & Flower & Infusion & Oral & 36 & 0.055 \\
\hline Erica ciliaris L. & El Khlenj & Leaf & Infusion & Oral & 53 & 0.081 \\
\hline Erica multiflora $\mathrm{L}$. & El Khlenj & Flower & Decoction & Oral & 5 & 0.008 \\
\hline Erica scoparia L. & El Khlenj & Leaf & Infusion & Oral & 14 & 0.021 \\
\hline Erica terminalis Salisb. & El Khlenj & Flower & Decoction & Oral & 10 & 0.015 \\
\hline Erica umbellata $\mathrm{L}$. & El Khlenj & Flower & Infusion & Oral & 8 & 0.012 \\
\hline \multicolumn{7}{|l|}{ Euphorbiaceae } \\
\hline Mercurialis annua L. & Hrriyga Lmelsa & Whole plant & Decoction & Topical & 05 & 0.008 \\
\hline \multicolumn{7}{|l|}{ Fabaceae } \\
\hline Cicer arietinum L. & Hommes & Seed & Decoction & Oral & 18 & 0.027 \\
\hline \multicolumn{7}{|l|}{ Gentianaceae } \\
\hline Centaurium erythraea Rafn & Merarat El hnech & Leaf & Decoction & Topical & 17 & 0.026 \\
\hline \multicolumn{7}{|l|}{ Grossulariaceae } \\
\hline Ribes nigrum L. & Kashmesh khel & Leaf & Decoction & Oral & 56 & 0.085 \\
\hline \multicolumn{7}{|l|}{ Lamiaceae } \\
\hline Convolvulus althaeoides L. & Louwaya & Leaf & Decoction & Oral & 01 & 0.002 \\
\hline Lavandula officinalis Chaix. & Lkhzama & Flower & Infusion & Oral & 112 & 0.170 \\
\hline Marrubium vulgare L. & Merriwt & Leaf & Other & Topical & 69 & 0.105 \\
\hline Origanum vulgare L. & Merdkkouch & Leaf & Infusion & Oral & 83 & 0.126 \\
\hline \multicolumn{7}{|l|}{ Myrtaceae } \\
\hline Myrtus communis L. & Rayhan & Leaf & Decoction & Topical & 56 & 0.0185 \\
\hline Pimenta dioica (L.) Merr. & Nwiwira & Fruit & Infusion & Dermal & 08 & 0.012 \\
\hline \multicolumn{7}{|l|}{ Pedaliaceae } \\
\hline Sesamum indicum L. & Jenjlane & Seed & Infusion & Oral & 07 & 0.011 \\
\hline \multicolumn{7}{|l|}{ Poaceae } \\
\hline Agropyrum repens (L.) P.B. & Njem & Rhizome & Decoction & Oral & 76 & 0.116 \\
\hline Festuca glauca Vill. & Aguzmir & Seed & Infusion & Oral & 05 & 0.008 \\
\hline Eleusine indica (L.) Gaertn. & Njem & Whole plant & Decoction & Oral & 01 & 0.002 \\
\hline Zea mays L. & Dra & Whole plant & Decoction & Oral & 79 & 0.120 \\
\hline \multicolumn{7}{|l|}{ Ranunculaceae } \\
\hline Nigella sativa $\mathrm{L}$. & Lhabba Ssawda & Seed & Decoction & Oral & 138 & 0.210 \\
\hline \multicolumn{7}{|l|}{ Rhamnaceae } \\
\hline Zizyphus vulgaris Lam. & Zefzouf & Fruit & Other & Oral & 162 & 0.247 \\
\hline \multicolumn{7}{|l|}{ Rosaceae } \\
\hline Eriobotrya japonica (Thunb.) Lindl. & Lemzah & Leaf & Infusion & Oral & 02 & 0.003 \\
\hline Prunus cerasus L. & Habb Lmlouk & Fruit & Infusion & Oral & 19 & 0.029 \\
\hline \multicolumn{7}{|l|}{ Rutaceae } \\
\hline Citrus limon (L.) Osbeck. & Lhamed & Fruit & Other & Oral & 06 & 0.009 \\
\hline Citrus limetta Risso. & Lhamed Beldi & Fruit & Cooked & Oral & 06 & 0.009 \\
\hline Citrus $\times$ aurantium L. & Larnej & Flower & Cooked & Oral & 25 & 0.038 \\
\hline Citrus reticulata Blanco. & Lmandarine & Fruit & Cooked & Oral & 01 & 0.002 \\
\hline \multicolumn{7}{|l|}{ Urticaceae } \\
\hline Urtica dioica L. & Lhurriga & Whole plant & Decoction & Topical & 38 & 0.058 \\
\hline
\end{tabular}


Table 2 Catalog of medicinal plants used to treat cystitis problems in the Rif, Morocco (Continued)

\begin{tabular}{|c|c|c|c|c|c|c|}
\hline Family and scientific name & Vernacular name & Used parts & Preparation mode & Route of administration & UR & MUV \\
\hline Urtica urens $\mathrm{L}$. & Lhurriga & Whole plant & Decoction & Topical & 14 & 0.021 \\
\hline \multicolumn{7}{|l|}{ Zygophylaceae } \\
\hline Tribulus terrestris L. & Ders Elajouz & Whole plant & Cooked & Dermal & 02 & 0.003 \\
\hline
\end{tabular}

\section{Discussion}

Our analysis of the results shows that both sexes are involved in phytotherapy. But, the numbers of male informants were more important than those of females. Men were predominantly represented in the sampling because of working. Because of the customs and traditions of the inhabitants of the Rif region, women must remain at home. They tend to abide by religious laws and close down the community. This explains the absence of females in the field during our discussions. This result reinforces the conclusions of other ethnobotanical national and international investigations [13-17] which have besides verified that males are more popular for vegetative information. For age groups, results revealed that interviewees above 50 years old had higher knowledge of medicinal species, while interviewees age less than 30 years old were less informed about it; this is due to the high secrecy of ancestral knowledge by older peoples. Concerning the academic level, our results revealed that the bulk of the informants $(43 \%)$ were illiterate. Preceding ethnobotanical investigation studies have comparable conclusions $[14,18]$. This means that with a greater level of education, the experience of traditional phytotherapy decreases. Consequently, advanced instruction diminishes the ancestral therapeutic experience of the young generation $[19,20]$.

The floristic analysis showed that a total of 60 plant species belonging to 51 genera and 31 botanical families were commonly utilized by local people in the therapy of cystitis. The botanical family Apiaceae was described by the most important number of medicinal plants $(7$ species) followed by Ericaceae with 6 species. The determined results of MUV noted that Capparis spinosa L. was ranked first (MUV=0.277) followed by Apium graveolens L. (MUV=0.267) and Zizyphus vulgaris Lam. (MUV=0.247). These results are compared to other studies especially in Morocco and Fars Province of Iran $[20,21]$. These plant species producing leading MUV must be further evaluated for toxicological, phytochemical, and pharmacological investigations to know their active components for an efficient and non-toxic medicine extraction.

The interview result revealed that leaf is the most frequently used part of the plants $41.5 \%$ of the total, followed by the whole plant (26.5\%) and fruit (10\%).
The selection of leaves was due to its natural availability, easy gathering, and simplicity in herbal remedy preparation. Besides, the leaves are the site of photosynthesis and sometimes the storage of the secondary metabolites active for the pharmaceutical properties of the medicinal plant. Similar results indicated that the leaf is used as a principal part of plants in phytotherapy in different studies [22-26]. The principal method of remedy preparation described by our interviewees was decoction (55\%). The frequent employment of the decoction can be justified by the evidence that this method makes it possible to conserve the effective multiple ingredients and attenuates or eliminates out the poisonous result of some plant constituents. Ethnobotanical researches carried in many regions of the globe discovered that the majority of informants prepared herbal remedies by decoction and infusion $[13,17,27-29]$. This result confirms that there is a continual transfer of information on the effectiveness of medicinal plants between the people of Morocco. Concerning the route of administration, the main route of application for herbal medicines was oral (82.4\%). Moreover, the oral form of treatment is a preferred route all over the planet [18, 30-37]. The predominance of oral treatment can be explained by the fact that cystitis is a common internal disease that is decimating the health of the Rif's population.

\section{Conclusion}

In light of the results obtained in this study, medical plants appear to continue to play a pivotal role in covering the basic needs of the health coverage system of the local population living in the Rif region notwithstanding technological progress in modern health. The sum of plant species used by informants to treat cystitis is also evidence that this region is full of medical knowledge inherited from generations ago.

In light of these encouraging results, additional research is suggested on the sustainable and reasonable use and conservation of medicinal plant species. Finally, it is advisable to conduct pharmacological, phytochemical, and toxicological investigations on these species that have been inventoried for laboratory validation of ancestral uses of these plants and to obtain the traditional medicine Bios. 


\section{Appendix}

Appendix A

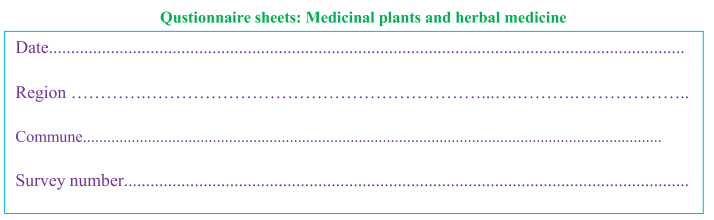

\section{Informant:}

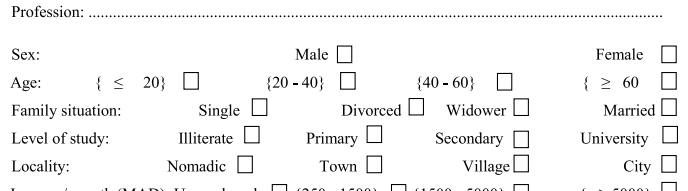

Income / month (MAD): Unemployed $\square\{250-1500\} \square\{1500-5000\} \square \quad\{\geq 5000\} \square$

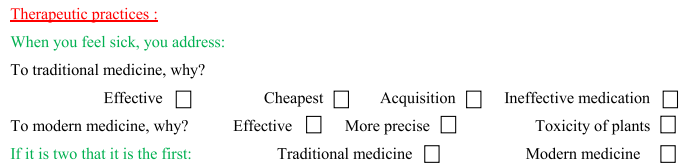

If it is two that it is the first: $\quad$ Traditional medicine $\square \quad$ Modern medicine $\square$

Vegetal material:

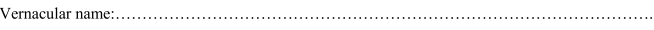

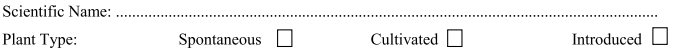

$\begin{array}{llrr}\text { Plant Type: } & \text { Spontaneous } \square & \text { Cultivated } \square & \text { Introduced } \\ \text { Use of the plant: } & \text { Therapeutic } \square & \text { Cosmetic } \square & \text { Other } \square\end{array}$

Harvesting technique: $\quad$ Manual $\square \quad$ Mechanical $\square$

Harvest Time: $\quad$ Summer $\square \quad$ Fall $\square \quad$ Winter $\square \quad$ Spring $\square \quad$ Any year $\square$

Drug preparation: $\quad$ Plant alone $\square \quad$ Possible association (of plants) $\quad \square$

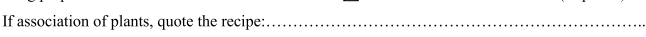

Use of the plant: $\quad$ Fresh $\square \quad$ Desiccated $\square$ After treatment

If desiccated, drying method: $\quad$ Sun exposure $\square \quad$ In the Shade $\square$

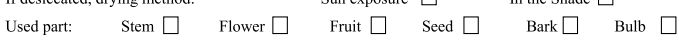
Root $\square \quad$ Rhizome $\square \quad$ Leaf $\square$ Whole plant $\square \quad$ Other combination $\square$

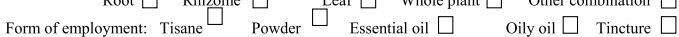

Method of preparation: Infusion $\square$ Decoction $\square$ Cataplasm $\square \quad$ Raw $\square$ cooked $\square \quad$ Other $\square$ Dose used: $\quad$ Pinch $\square \quad$ Handle $\square \quad$ Spoonful $\square$ Precise Dose: Quantity in g/glass: ............ Quantity in g/ liter: .......... Other: .................. Administration mode: $\quad$ Oral $\square \quad$ Massage $\square \quad$ Rinse $\square \quad$ Swabbing $\square \quad$ Other $\square$ Dosage: number of doses per day:

For children: 1 1time/day $\quad \square \quad$ 2time/day $\square \quad$ 3time/day $\square \quad$ Other $\square$ For adults: $\quad 1$ time/day $\square \quad$ 2time/day $\square \quad$ 3time/day $\square \quad$ Other $\square$

For older people: $\quad 1$ time / day $\square \quad 2$ time /day $\square \quad$ 3time/day $\square \quad$ Other $\square$

Length of Use: $\quad$ One Day $\square \quad$ A Week $\square \quad$ One month $\square \quad$ Until healing $\square$

Conservation method: Sheltered from the light $\square \quad$ Exposed to light $\square \quad$ Other $\square$

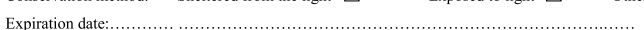

Use.

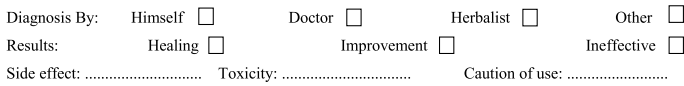

\section{Abbreviations}

MUV: Medicinal use plants; UR: Use report; MPs: Medicinal plants

\section{Acknowledgements}

We wish to send our heartfelt thanks to all the leaders and residents of the Rif region for their help and all sellers of medicinal plants (Attar). We also extend our acknowledgements to all those who contributed to the realization of this work.

\section{Plant identification}

Botanical identification of the plant parts was carried out at Plant, Animal Productions and Agro-industry Laboratory, Department of Biology.

\section{Authors' contributions}

NC carried out field research in the Rif; compiled the literature sources, data analysis, and interpretation; and wrote the manuscript, and performed data analysis. $\mathrm{HO}$ helped in data and made a substantial contribution to data analysis. LZ designed the research and identification of plant species. All authors read and approved the final manuscript.

\section{Funding}

This research did not receive any specific grant from funding agencies in the public, commercial, or not-for-profit sectors.

\section{Availability of data and materials}

All data collected and analyzed in this paper are included in the article and attached in the form of "Appendices" as additional files. Medicinal plant specimens are deposited in our university.

\section{Declarations}

\section{Ethics approval and consent to participate}

The study was carried out following the recommendations of the Code of Ethics of the International Society of Ethnobiology. Ethics approval was authorized by the Ethics Committee of Plant, Animal Productions and Agroindustry Laboratory, Department of Biology, Faculty of Sciences, Ibn Tofail University, through No. NHEL/06/06/2016. During this discussion, the research objectives and interview procedure were explained to each informant, and confidentiality was assured. Consent for audio recording was also obtained. Interviewees were informed that the intentions of the research were not for commercial purposes or other interests but for academic reasons. Informants provided verbal informed consent to share in this study; they were free to withdraw their knowledge at any point in time. After informing the committee that we had only obtained the oral consent of the informants, the committee immediately accepted the completion of this study.

\section{Consent for publication}

Consent for publication was obtained from participants.

\section{Competing interests}

The authors declare that they have no competing interest.

\section{Author details}

${ }^{1}$ Higher School of Education and Training, Berrechid, University Hassan, 1st, 50 Rue Ibnou Lhaytham B.P. 577, 26002 Settat, Morocco. ${ }^{2}$ Plant, Animal Productions and Agro-industry Laboratory, Department of Biology, Ibn Tofail University, B.P. 133, 14000 Kenitra, Morocco.

Received: 19 November 2020 Accepted: 15 March 2021

Published online: 01 April 2021

\section{References}

1. Ait Miloud K (2011) L'infection urinaire: expérience du laboratoire de microbiologie de l'hôpital des spécialités de Rabat, PhD Thesis

2. 2018 WHO (2018) World Health Organization: high levels of antibiotic resistance found worldwide, new4 data shows. [http://www.who.int/ mediacentre/news/ releases/2018/antibiotic-resistance-found/en/] published: 2018 . Accessed

3. HCP (2014) Haut-Commissariat au Plan, Recensement de la Population et de I'Habitat, Maroc,

4. DMNM (2018) Direction de la Météorologie Nationale, Maroc.

5. Sijelmassi A (1993) Les plantes médicinales du Maroc, 3ème édition Fennec, Casablanca Moroc

6. Fennane M, Ibn Tattou M, El Oualidi J (2014) Flore pratique du Maroc, Dicotylédones (pp), Monocotylédones, Trav. L'Institut Sci. Rabat Sér. Bot., vol. 40

7. Fennane M, Tattou MI, Valdés B (1998) Catalogue des plantes vasculaires rares, menacées ou endémiques du Maroc. Herbarium Mediterraneum Panormitanum

8. Fennane M, Tattou MI, Mathez J, Quézel P (1999) Flore pratique du Maroc: manuel de détermination des plantes vasculaires. Pteridophyta, Gymnospermae, Angiospermae (Lauraceae-Neuradaceae). Institut scientifique

9. Valdés B (2002) Catalogue des plantes vasculaires du Nord du Maroc, incluant des clés d'identification, vol. 1. Editorial CSIC-CSIC Press

10. Dossou ME, Houessou GL, Lougbégnon OT, Tenté AHB, Codjia JTC (2012) Etude ethnobotanique des ressources forestières ligneuses de la forêt 
marécageuse d'Agonvè et terroirs connexes au Bénin. Tropicultura 30(1):4148.

11. Tabuti JR, Lye KA, Dhillion SS (2003) Traditional herbal drugs of Bulamogi, Uganda: plants, use and administration. J. Ethnopharmacol 88(1):19-44. https://doi.org/10.1016/S0378-8741(03)00161-2

12. Yaseen G, Ahmad M, Sultana S, Alharrasi AS, Hussain J, Zafar M (2015) Ethnobotany of medicinal plants in the Thar Desert (Sindh) of Pakistan. J Ethnopharmacol 163(p):43-59. https://doi.org/10.1016/j.jep.2014.12.053

13. Ahmad M, Zafar M, Shahzadi N, Yaseen G, Murphey TM, Sultana S (2018) Ethnobotanical importance of medicinal plants traded in Herbal markets of Rawalpindi-Pakistan. J. Herb. Med. 11(p):78-89. https://doi.org/10.1016/j. hermed.2017.10.001

14. Benkhnigue O, Zidane L, Fadli M, Elyacoubi H, Rochdi A, Douira A (2010) Etude ethnobotanique des plantes médicinales dans la région de Mechraâ Bel Ksiri (Région du Gharb du Maroc). Acta Bot. Barcinonensia 53:191-216

15. Benlamdini N, Elhafian M, Rochdi A, Zidane $L$ (2014) Étude floristique et ethnobotanique de la flore médicinale du Haut Atlas oriental (Haute Moulouya). J Appl Biosci 78(1):6771-6787. https://doi.org/10.4314/jab. v78i1.17

16. Chaachouay N, Benkhnigue O, El Ibaoui H, El Ayadi R, Zidane L, (2019) Medicinal plants used for diabetic problems in the Rif, Morocco, Ethnobotany Research and Applications, Medicinal plants used for diabetic problems in the Rif, Morocco.

17. Rhafouri R, Aafi A, Zair T, Strani B, El Omari M, Ghanmi M (2014) Ethnobotanical study of medicinal plants in Ifran's National Park (Morocco)

18. Chaachouay N, Benkhnigue O, Zidane L (2020) Ethnobotanical study aimed at investigating the use of medicinal plants to treat nervous system diseases in the Rif of Morocco. J. Chiropr. Med. 19(1):70-81. https://doi.org/1 0.1016/j.jcm.2020.02.004

19. Kidane L, Gebremedhin G, Beyene T (2018) Ethnobotanical study of medicinal plants in Ganta Afeshum District, Eastern Zone of Tigray, Northern Ethiopia. J. Ethnobiol. Ethnomedicine 14(1):64. https://doi.org/10.1186/s13 002-018-0266-z

20. Chaachouay N, Benkhnigue O, Fadli M, El Ibaoui H, Zidane L (2019) Ethnobotanical and ethnopharmacological studies of medicinal and aromatic plants used in the treatment of metabolic diseases in the Moroccan Rif, Heliyon, p e02191

21. Chaachouay N, Benkhnigue O, Khamar H, Zidane L (2020) Ethnobotanical study of medicinal and aromatic plants used in the treatment of genitourinary diseases in the Moroccan Rif. J Mater Environ Sci 11(1):15-29.

22. El-Hilaly J, Hmammouchi M, Lyoussi B (2003) Ethnobotanical studies and economic evaluation of medicinal plants in Taounate province (Northern Morocco). J. Ethnopharmacol. 86(2-3):149-158. https://doi.org/10.1016/S03 78-8741(03)00012-6

23. Asase A, Akwetey GA, Achel DG (2010) Ethnopharmacological use of herbal remedies for the treatment of malaria in the Dangme West District of Ghana. J. Ethnopharmacol. 129(3):367-376. https://doi.org/10.1 016/j.jep.2010.04.001

24. Bammi J, Douira A (2002) Les plantes médicinales dans la forêt de l'achach (plateau central, Maroc)

25. Chaachouay N, Benkhnigue O, Fadli M, El Ibaoui H, El Ayadi R, Zidane L (2019) Ethnobotanical and Ethnopharmacological Study of Medicinal and Aromatic Plants Used in the Treatment of Respiratory System Disorders in the Moroccan Rif. Ethnobotany Res Appl 18(6):1-16. http://dx.doi.org/10.32 859/era.18.22.1-17.

26. Chaachouay N, Benkhnigue O, Douira A, Zidane L (2021) Poisonous medicinal plants used in the popular pharmacopoeia of the Rif, northern Morocco, Toxicon, pp 24-32

27. Douiri E, El Hassani M, Bammi J, Badoc A, Douira A (2007) Plantes vasculaires de la Moyenne Moulouya (Maroc oriental). Bull Soc Linn Bordx. 142(p):409-438

28. Boadu A A, Asase A (2017) Documentation of herbal medicines used for the treatment and management of human diseases by some communities in southern Ghana, Evid Based Complement Alternat Med. Volume 2017, Article ID 3043061, 12 pages. https://doi.org/10.1155/2017/3043061.

29. Chaachouay N, Benkhnigue O, Fadli M, El Ayadi R, Zidane L (2019) Ethnobotanical study of medicinal plants used to treat osteoarticular diseases in the Moroccan Rif, Morocco. J Pharm Pharmacogn Res 7(6): 454-470
30. Mohamadi N, Sharififar F, Koohpayeh A, Daneshpajouh M (2015) Traditional and ethnobotanical uses of medicinal plants by ancient populations in Khabr and Rouchon of Iran

31. Addisie MB (2012) Assessment of drinking water quality and determinants of household potable water consumption in Simada District, Ethiopia, PhD Thesis, Cornell University

32. Andrade $J M$, Lucero Mosquera $H$, Armijos C (2017) Ethnobotany of indigenous Saraguros: medicinal plants used by community healers "Hampiyachakkuna" in the San Lucas parish, southern Ecuador. BioMed Res Int 2017

33. Betti JL, Yongo OD, Mbomio DO, Iponga DM, Ngoye A (2013) An ethnobotanical and floristical study of medicinal plants among the Baka Pygmies in the periphery of the Ipassa-Biosphere reserve, Gabon. Eur J Med Plants:174-205

34. Meyanungsang K, Teresa M, Kaisarun All, David H, James K, Subramanyam R, Vemulpada J, Jamie F (2015) An ethnobotanical study of medicinal plants of Chungtia village, Nagaland, India. J. Ethnopharmacol 166:5-17

35. Ullah M, Usman Khan M, Adeel M, Malek RN, Majid H, Wazir SM, Daud M, Shinwari ZK (2013) An ethnobotanical survey of indigenous medicinal plants in Wana district south Waziristan agency, Pakistan. J Ethnopharmacol 150(3):918-924. https://doi.org/10.1016/j.jep.2013.09.032

36. Chaachouay N, Douira A, Zidane L (2021) COVID-19, prevention and treatment with herbal medicine in the herbal markets of Salé Prefecture, North-Western Morocco. European Journal of Integrative Medicine. Volume 42, pp 101285. https://doi.org/10.1016/j.eujim.2021.101285

37. Chaachouay N, Benkhnigue O, Douira A, Zidane L (2021) Poisonous medicinal plants used in the popular pharmacopoeia of the Rif, northern Morocco. Toxicon. Volume 189, pp 24-32. https://doi.org/10.1016/j.toxicon.2 020.10 .028

\section{Publisher's Note}

Springer Nature remains neutral with regard to jurisdictional claims in published maps and institutional affiliations.

\section{Submit your manuscript to a SpringerOpen ${ }^{\circ}$ journal and benefit from:}

- Convenient online submission

Rigorous peer review

- Open access: articles freely available online

High visibility within the field

- Retaining the copyright to your article

Submit your next manuscript at $\boldsymbol{\nabla}$ springeropen.com 